\title{
Glucose production and utilization in non-pregnant, pregnant and lactating ewes
}

\author{
BY STEPHEN WILSON
}

Hill Farming Research Organisation, Bush Estate, Penicuik, Midlothian EH26 OPY

\author{
AND J. C. MACRAE \\ Department of Energy Metabolism, Rowett Research Institute, Bucksburn, \\ Aberdeen $A B 2$ 9SB
}

\author{
AND P. J. BUTTERY \\ Department of Applied Biochemistry and Food Science, University of Nottingham, School \\ of Agriculture, Sutton Bonington, Loughborough, Leicestershire LE12 5RD
}

\section{(Received 13 December 1982 - Accepted 21 March 1983)}

1. By using continuous infusions of ${ }^{3} \mathrm{H}$ - and ${ }^{14} \mathrm{C}$-labelled substrates, three-pool models, incorporating rumen propionate, plasma glucose and blood carbon dioxide were constructed to determine the contribution of propionate to glucose in non-pregnant, pregnant (mid and late) and lactating hill ewes.

2. Although the intakes of non-pregnant and pregnant ewes were the same $(1200 \mathrm{~g}$ dried grass/d) and resulted in similar levels of propionate production $(33 \mathrm{~g} \mathrm{C} / \mathrm{d}$ ), glucose production rate (GPR) increased from $44 \mathrm{~g} \mathrm{C/d}$ in the non-pregnant ewes to $62 \mathrm{~g} \mathrm{C} / \mathrm{d}$ in the ewes carrying twins in late pregnancy. In lactating ewes given $2500 \mathrm{~g}$ dried grass/d, propionate production increased to $56 \mathrm{~g} \mathrm{C} / \mathrm{d}$ and GPR increased to 93 and $104 \mathrm{~g} \mathrm{C} / \mathrm{d}$ in ewes suckling single and twin lambs respectively.

3. There was an increase in the percentage of the propionate resource which was diverted to glucose, from $37 \%$ in the non-pregnant ewes and ewes in mid-pregnancy, to $55 \%$ in late pregnancy and $60 \%$ in lactation. In spite of this apparent metabolic adaptation to the additional requirements for glucose, approximately $55 \%$ of the glucose-C was supplied by metabolites other than propionate and $\mathrm{CO}_{2}$.

4. From the determination of plasma glycerol concentrations it was estimated that the maximum possible contribution of glycerol- $\mathrm{C}$ to glucose was only $8-12 \mathrm{~g} \mathrm{C} / \mathrm{d}$. The remaining $40 \%$ of the glucose-C could not be accounted for and could have been derived from non-essential amino acids (NEAA).

5. In the non-pregnant and pregnant ewes only $62 \%$ of the GPR was oxidized to $\mathrm{CO}_{2}$. In the lactating ewes only 49 and $30 \%$ of the GPR was oxidized to $\mathrm{CO}_{2}$ in the ewes suckling single and twin lambs respectively.

6. In the majority of cases there was a marked similarity between the amounts of glucose-C apparently derived from NEAA and the amount of glucose-C which was not oxidized to $\mathrm{CO}_{2}$.

The importance of glucose to the ruminant is now well established (see reviews by Leng, 1970; Bergman, 1973; Young, 1977; Lindsay, 1978), as is the fact that very little glucose per se is absorbed from the digestive tract when roughage-based diets are fed (Lindsay, 1970). The animals must therefore obtain their glucose from gluconeogenic precursors, the major one being propionate, which provides $30-50 \%$ of the glucose-carbon produced in the non-pregnant, non-lactating animal (Bergman et al. 1966; Leng et al. 1967; Judson \& Leng, 1968; Steel \& Leng, 1973; Brockman \& Greer, 1980).

In pregnancy and lactation the glucose requirements for the nutrition of the fetus and for lactose production, respectively, are considerably greater than in non-pregnant and non-lactating animals. However, in certain practical situations, such as when ewes are grazing hill-type vegetation in the late winter and early spring, these demands can coincide with a period when the availability of dietary nutrients is insufficient to maintain an adequate level of nutrition (Hill Farming Research Organisation, 1979). It was therefore of interest to examine whether in such situations the ewe has an ability to adapt its 
metabolism so as to convert more of its propionate resource to glucose in order to satisfy the extra demands of the fetus and the mammary gland.

This paper describes experiments which examine the propionate metabolism of Scottish Blackface ewes given a fixed intake of forage throughout pregnancy and the same forage, but to a higher level of intake, through lactation. The results obtained suggest that the ewe can in fact increase the proportion of the propionate- $\mathrm{C}$ which is converted to glucose during late pregnancy and early lactation.

A preliminary report of part of this study has recently been published (Wilson et al. 1983).

\section{MATERIALS AND METHODS}

\section{Animals and diets}

Ten 5-year-old Blackface ewes of similar weight (range $50-56 \mathrm{~kg}$ ) and each fitted with a permanent rumen cannula, were individually housed in slatted-floor pens and given $1200 \mathrm{~g}$ dried grass $/ \mathrm{d}(600 \mathrm{~g}$ given at 08.00 and 17.00 hours; providing $(\mathrm{g} / \mathrm{kg})$ : organic matter 910 , digestible organic matter 690 , nitrogen 26). Seven of the ewes were selected at random and mated to a Blackface ram and, at approximately day 75 of gestation, they were X-rayed for pregnancy diagnosis and possible determination of fetal numbers (Rowett Research Institute, Aberdeen). Those which were pregnant were given a mixture of dried grass ad lib. and $400 \mathrm{~g}$ concentrate supplement (Ewemax, providing $(\mathrm{g} / \mathrm{kg})$ : crude protein $(\mathrm{N} \times 6 \cdot 25)$ 140, urea 14, fibre 50, magnesium 7; SAI Ltd, Edinburgh)/d for approximately $7 \mathrm{~d}$ pre-partum and $5 \mathrm{~d}$ post partum. Beginning on day 6 post partum the intake of concentrate was gradually reduced and the intake of dried grass increased until by day 15 intake was restricted to $2500 \mathrm{~g}$ dried grass.

A low-copper mineral lick (F. S. L. Bells, Corsham) was always available.

\section{General procedures}

At approximately days 76 (mid-pregnancy experiment) and 120 (late pregnancy experiment) of gestation the pregnant ewes, together with the non-pregnant ewes, were moved into metabolism crates in constant light at $16^{\circ}$. Feed was given by continuous feeder for 7-10 d before and throughout a series of radioactive-tracer infusion experiments which were spread over $10 \mathrm{~d}$ (see p. 305 for details). Ewes were then returned to the slatted-floor pens and fed twice daily as before.

The non-pregnant ewes were not used again. The pregnant ewes were returned to the slatted-floor pens for lambing. At $15 \mathrm{~d}$ following parturition the ewes were moved back into metabolism crates for the lactation experiment and subjected to similar feeding and infusion procedures as described previously. Lambs were loose-housed in the same room as the ewes and only put into the metabolism crates to be suckled by the ewes six times every $24 \mathrm{~h}$ for 5 min each time. This procedure appeared to cause very little stress to ewes or lambs following a $24 \mathrm{~h}$ 'settling-in' period. This was supported by the observation that maternal plasma glucose concentrations were similar before and after the separation. In addition, the lamb growth rates achieved were quite reasonable (see Fig. 2), which suggested that the milk supply had not been adversely affected.

\section{Isotopes, infusates and infusions}

The tracers, $\left[\mathrm{U}-{ }^{14} \mathrm{C}\right] \mathrm{glucose}(260 \mathrm{mCi} / \mathrm{mmol}),\left[6-{ }^{3} \mathrm{H}\right]$ glucose $(13 \mathrm{Ci} / \mathrm{mmol}), \mathrm{NaH}^{14} \mathrm{CO}_{3}$ $\left(58 \mathrm{mCi} / \mathrm{mmol}\right.$ ), and $\left[2{ }^{14} \mathrm{C}\right]$ propionic acid (sodium salt; $57 \mathrm{Ci} / \mathrm{mmol}$ ) were purchased from Amersham International, Amersham, Bucks. The $\left[{ }^{14} \mathrm{C}\right]$ - and $\left[{ }^{3} \mathrm{H}\right]$ glucose and the $\mathrm{NaH}^{14} \mathrm{CO}_{3}$ were prepared in sterile saline ( $9 \mathrm{~g}$ sodium chloride/l) containing the appropriate carrier $(1 \mathrm{mCi} / \mathrm{mmol})$. The $\left[2-{ }^{14} \mathrm{C}\right]$ propionate was prepared in autoclaved water, as recommended by Wilson \& MacRae (1977), containing carrier sodium propionate $(1 \mathrm{mCi} / \mathrm{mmol})$. All 
infusates were prepared the day before each infusion and kept at $2^{\circ}$ before infusion. Samples were taken before and after each infusion to check for any loss of activity. When $\mathrm{NaH}^{14} \mathrm{CO}_{3}$ radioactivity was measured, $1 \mathrm{ml}$ of $0.2 \mathrm{M}$-EDTA (tetrasodium salt) was added to the NE 260 scintillator before the addition of the $\mathrm{NaH}^{14} \mathrm{CO}_{3}$ to prevent loss of radioactivity as ${ }^{14} \mathrm{CO}_{2}$ (MacRae \& Wilson, 1978).

Combinations of tracers were infused over a $10 \mathrm{~d}$ period (day $1 \mathrm{NaH}^{14} \mathrm{CO}_{3}+\left[{ }^{3} \mathrm{H}\right] \mathrm{glucose}$, day $4\left[{ }^{14} \mathrm{C}\right]$ glucose $+\left[{ }^{3} \mathrm{H}\right]$ glucose, day $7\left[2{ }^{14} \mathrm{C}\right]$ propionate $+\left[{ }^{3} \mathrm{H}\right]$ glucose, day $10\left[{ }^{3} \mathrm{H}\right]$ glucose $)$. $\left[{ }^{14} \mathrm{C}\right]$-Glucose $(10-24 \mu \mathrm{Ci} / \mathrm{h}),\left[{ }^{3} \mathrm{H}\right]$ glucose $(11-33 \mu \mathrm{Ci} / \mathrm{h})$ and $\mathrm{NaH}^{14} \mathrm{CO}_{3}(10-33 \mu \mathrm{Ci} / \mathrm{h})$ were infused into the blood via one of two jugular vein catheters, which had been implanted at least $24 \mathrm{~h}$ previously in order to allow glucose metabolism to return to normal following the catheterization procedure (Wilson et al. 1979). $\left[2-{ }^{14} \mathrm{C}\right] \mathrm{Propionate}(6-13 \mu \mathrm{Ci} / \mathrm{h})$ was infused into the anterior part of the rumen using a specially designed piece of apparatus which could also be used for simultaneous sampling of rumen fluid (Wilson, 1982). All infusates were kept in an ice bath and were administered using a peristaltic pump (Ismatec, Grant Instruments Ltd, Cambridge). The infusion time for all infusates was approximately $18 \mathrm{~h}$.

\section{Sampling of body fluids and routine analyses}

Blood. During each infusion four to five samples $(10 \mathrm{ml})$ were withdrawn from the non-infusion jugular catheter over a $10-15 \mathrm{~min}$ period between approximately 950 and $1050 \mathrm{~min}$. A subsample of whole blood $(3-4 \mathrm{ml})$ was immediately dispensed into a McCartney bottle for the determination of the specific radioactivity (SRA) of ${ }^{14} \mathrm{CO}_{2}$ by the method of Leng \& Leonard (1965) as modified by MacRae \& Wilson (1978). The remainder was centrifuged $\left(13000 \mathrm{~g}\right.$ for $5 \mathrm{~min}$ ) at $2^{\circ}$ and the plasma stored at $-20^{\circ}$ for subsequent $\left[{ }^{14} \mathrm{C}\right]$ - and $\left[{ }^{3} \mathrm{H}\right]$ glucose-SRA assays (Jones, 1965) and the determination of glucose (Gutteridge \& Wright, 1968) and glycerol (Biochemica test combination kit for neutral fat and glycerol; Boehringer Corporation, London) concentrations. Minor modifications to the glucose-SRA assay procedure included the addition of carrier glucose before the deproteinization stage, with the evaporation stage being carried out in a freeze-drier, instead of on a hotplate. This eliminated the possibility of charring the glucose.

Rumen fluid. During each infusion four to five samples of rumen fluid $(20 \mathrm{ml})$ were withdrawn at 15-20 min intervals between 950 and $1050 \mathrm{~min}$. Concentrated sulphuric acid (two drops) was added and well mixed before storage at $-20^{\circ}$ before analysis for $\left[{ }^{14}\right.$ C]propionate-SRA (see below).

Urine. Urine (filtered through muslin) was collected into buckets containing $50 \mathrm{ml}$ toluene between 14 and $18 \mathrm{~h}$ of the infusion. If any sheep did not urinate naturally during these periods, a sample was obtained via a bladder catheter or by placing a hand over the ewe's nose to restrict breathing and stimulate urination (Corbett et al. 1971). Triplicate 4-5 ml subsamples of the bulk urine were dispensed into a McCartney bottle for the determination of the SRA of ${ }^{14} \mathrm{CO}_{2}$.

Immediately before each infusion the residual radioactivity in blood, urine and rumen fluid was monitored and, without exception, shown to be negligible.

\section{Analysis for propionate-SRA in rumen fluid}

Rumen fluid $(10-15 \mathrm{ml})$ was centrifuged $(15000 \mathrm{~g}$ for $15 \mathrm{~min})$ at $2^{\circ}$ and the supernatant fraction analysed for propionate concentration by gas-liquid chromatography (Ziolecki \& Kwiatkowska, 1973). The remainder of the supernatant fraction was acidified with $2 \mathrm{ml}$ $3 \mathrm{M}-\mathrm{H}_{2} \mathrm{SO}_{4}$ and steam-distilled into $2 \mathrm{ml} 1 \mathrm{M}$-sodium hydroxide. The distillate was collected

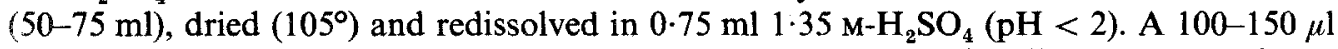
sample was injected on to a glass preparative column ( $9 \mathrm{~mm}$ outside diameter, $2 \cdot 1 \mathrm{~m}$ long; 
Pye Unicam Ltd, Cambridge) packed with $10 \%$ polyethylene glycol 400 monostearate (Pegosperse S-9; Campbell \& Co. Ltd, Croydon) on Chromosorb W (acid-washed 60-80 mesh; Phase Separations Ltd, Clwyd, Wales).

The majority of samples were analysed using linear temperature programming of the column $\left(2^{\circ} \mathrm{min} ; 105-140^{\circ}\right)$ following an initial $10-12 \mathrm{~min}$ at $105^{\circ}$. Total analysis time was approximately $45 \mathrm{~min} / \mathrm{sample}$. Some samples, however, were analysed under isothermal conditions at $105^{\circ}$ when analysis time ranged from 60 to $90 \mathrm{~min}$. Temperatures of the injector, detector and the $100: 1$ stream splitter were $165^{\circ}, 160^{\circ}$ and $150^{\circ}$ respectively and the flow-rates of $\mathrm{N}_{2}$ (carrier gas), hydrogen and air were 25,33 and $500 \mathrm{ml} / \mathrm{min}$ respectively.

The stream splitter was attached to a glass mixing coil $(150 \mathrm{~mm})$ through which $0.015 \mathrm{M}-\mathrm{NaOH}$ was pumped for absorption of the propionate. Bubbles of air were also drawn in to aid the mixing process. A chart recorder linked to the gas-liquid chromatograph indicated when the individual volatile fatty acids were coming off the column. The propionate (dissolved in approximately $5-10 \mathrm{ml}$ ) was collected into a pre-weighed scintillation vial, dried $\left(105^{\circ}\right)$ and redissolved in $1 \mathrm{ml}$ of a mixture containing $30 \mathrm{~g}$ metaphosphoric acid, $40 \mathrm{ml}$ formic acid and $2 \mathrm{~g} \alpha$-ethyl butyrate/1. A $0.25 \mathrm{ml}$ sample was taken for analysis of propionate concentration and the remainder was taken up in $12 \mathrm{ml} \mathrm{NE} 260$ scintillator and the ${ }^{14} \mathrm{C}$ activity measured. This method of analysis resulted in propionate recoveries of $>95 \%$ with no contamination between the acids.

\section{Terminology and calculations}

Plasma glucose, blood $\mathrm{CO}_{2}$ and rumen propionate production rates are defined as the rate at which each leaves its respective pool and does not return during the infusion experiment. The production rates were calculated by dividing the rate of infusion of radioisotope $(\mu \mathrm{Ci} / \mathrm{h})$

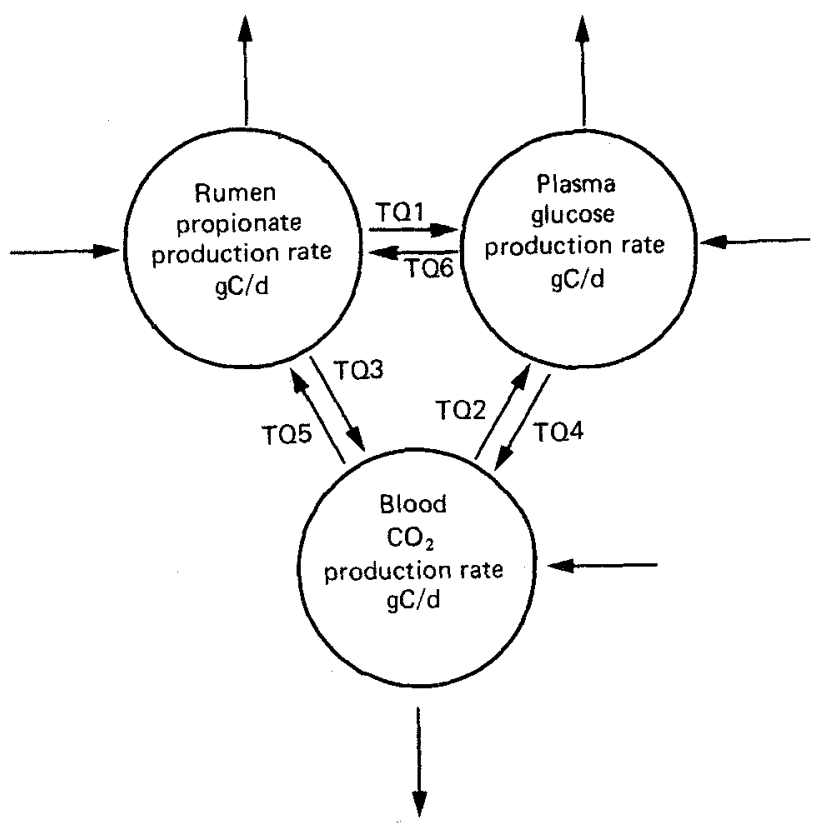

Fig. 1. The three-pool model of glucose metabolism used for the calculation of flows of carbon $(\mathrm{g} / \mathrm{d})$ into, out of and between rumen propionate, plasma glucose and blood carbon dioxide in non-pregnant, pregnant and lactating ewes. TQ, transfer quotient, for which the individual values are given in Table 2. 
by the plateau-SRA of the metabolite $(\mu \mathrm{Ci} / \mathrm{g} \mathrm{C}$ or $\mu \mathrm{Ci} / \mathrm{g} \mathrm{H})$. In the case of the $\mathrm{NaH}^{14} \mathrm{CO}_{3}$ infusions the urine was selected as the sampling site in preference to the blood (Prieto $e t$ al. 1983). The value for glucose production rate (GPR) for individual sheep was taken as the mean value obtained from the four estimates obtained with $\left[{ }^{3} \mathrm{H}\right]$ glucose on days 1,4 , 7 and 10 , but adjusted on the basis of the difference in GPR when $\left[{ }^{14} \mathrm{C}\right]$ glucose and $\left[{ }^{3} \mathrm{H}\right]$ glucose were infused together on day 4.

Transfer quotients (proportion of the product atoms derived from the substrate atoms; TQ) were calculated by dividing the plateau-SRA of the product $(\mu \mathrm{Ci} / \mathrm{g} \mathrm{C})$ by the plateau-SRA of the substrate $(\mu \mathrm{Ci} / \mathrm{g} \mathrm{C})$.

The $\mathrm{C}$ flows $(\mathrm{g} / \mathrm{d})$ into, out of and between the pools of rumen propionate, plasma glucose and blood $\mathrm{CO}_{2}$ were calculated by solving a series of simultaneous equations (similar to those described by Nolan et al. 1976) which were derived using the experimentally determined values for propionate, glucose and $\mathrm{CO}_{2}$ production rates $(\mathrm{gC} / \mathrm{d})$ and the respective secondary pool TQ. The three-pool model is illustrated in Fig. 1.

Because it was not possible to obtain all the necessary variables from every ewe on each occasion, it was not possible to construct individual models for every ewe. Instead, the models were derived from appropriate mean production rates and TQ.

\section{RESULTS}

\section{Production rates of metabolites}

Daily production rates of glucose (plasma), propionate (rumen) and $\mathrm{CO}_{2}$ (blood) are presented in Table 1.

The reason for the unbalanced number of animals used in estimating some of the variables was due to two contributing factors. First, to an incorrect diagnosis of the number of fetuses in some of the ewes (i.e. diagnosed: 3 ewes bearing singles and 4 ewes bearing twins; observed: 2 ewes bearing singles and 5 ewes bearing twins). In an attempt to even the balance for the lactation experiment one lamb was removed shortly after birth from one of the ewes suckling twins. One lamb from one of the remaining ewes suckling twins then fell sick and had to be removed. This left 4 ewes suckling singles and 3 ewes suckling twins. Second, practical difficulties were encountered during some of the isotope infusions.

There was no significant difference in the mean GPR when determined in the non-pregnant ewes during the mid-and late-pregnancy experiments. Although the GPR of the pregnant ewes measured in mid-pregnancy was slightly higher than the GPR of the non-pregnant ewes, the difference was not significant $(P>0.05)$. In late pregnancy the GPRs in ewes carrying single and twin lambs were $22 \%(P<0.05)$ and $42 \%(P<0.01)$ higher respectively than in the non-pregnant ewes given a similar level of intake. In the lactating ewes the relative increase in GPR (approximately $125 \%$ ) was slightly higher than the relative increase in level of intake (108\%), with the ewes suckling twin lambs having slightly higher GPR $(12 \%, P<0.05)$ than those suckling single lambs.

Propionate production rates were similar $(P>0.05)$ in non-pregnant and pregnant ewes given $1200 \mathrm{~g}$ dried grass $/ \mathrm{d}$. The increase in production in lactation $(70 \%)$ was not quite in proportion to the increase in intake.

Production rates of $\mathrm{CO}_{2}$ were similar $(P>0.05)$ in non-pregnant ewes and ewes in mid-pregnancy. There was, however, a trend $(P>0.05)$ towards a higher production in the ewes carrying twins in late pregnancy. Production rates were approximately $50 \%$ higher in the lactating ewes than in the non-pregnant ewes, but there was no significant difference between ewes suckling single or twin lambs $(P>0.05)$.

The TQ obtained during infusions of $\left[2-{ }^{14} \mathrm{C}\right]$ propionate, $\left[{ }^{14} \mathrm{C}\right]$ glucose and $\mathrm{NaH}^{14} \mathrm{CO}_{3}$ are summarized in Table 2. They have been included for comparison with values quoted in the literature; no further reference will be made to them. 


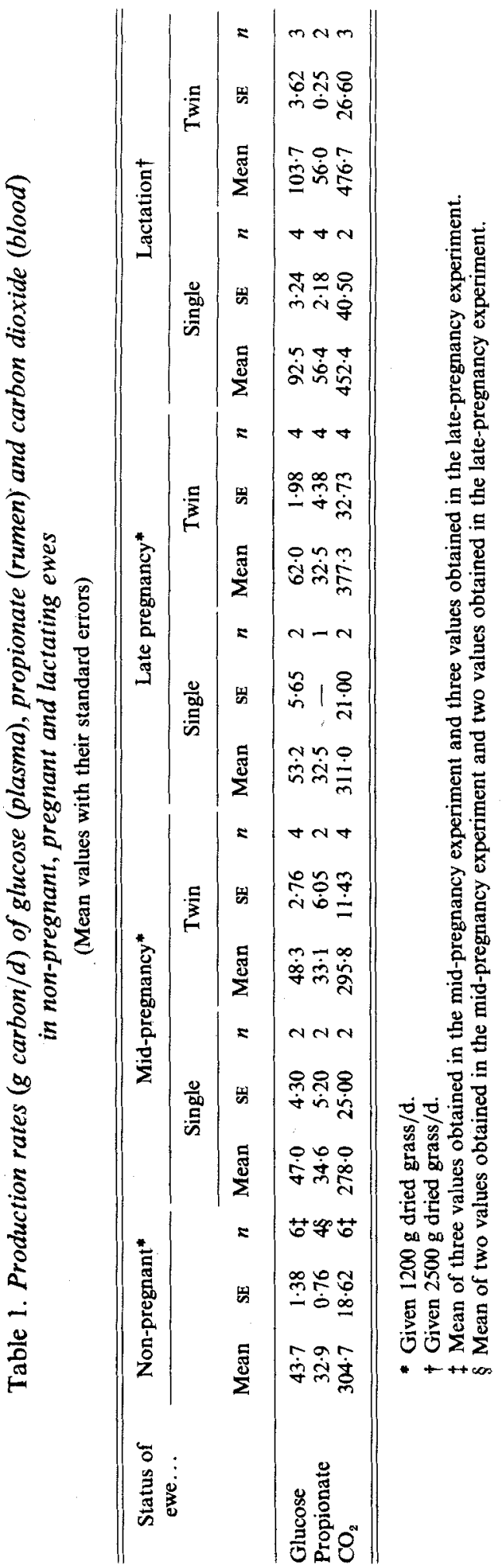




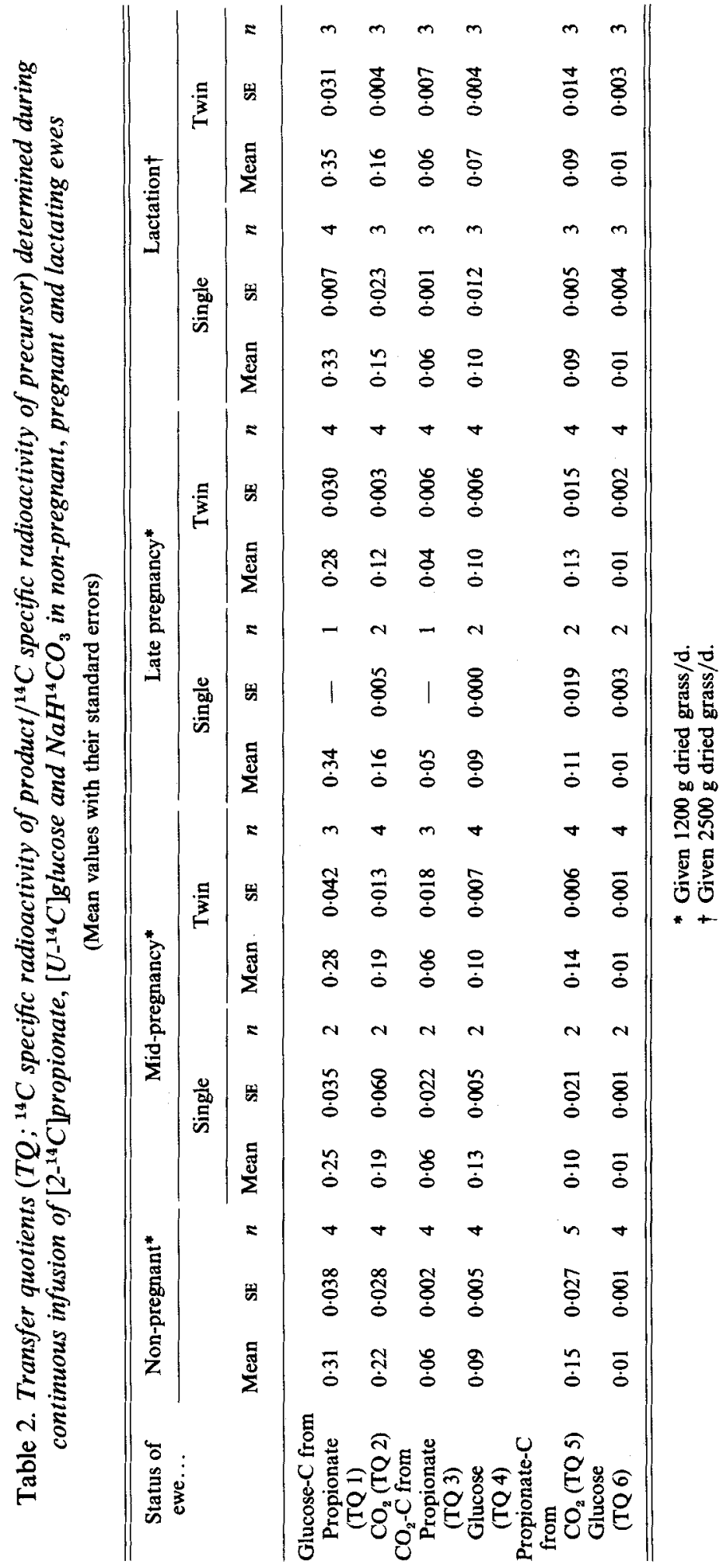


Table 3. The production and utilization of glucose in non-pregnant, pregnant and lactating ewes ( $g$ carbon/d)

\begin{tabular}{|c|c|c|c|c|c|c|c|}
\hline \multirow[t]{2}{*}{ Status of ewe... } & \multirow[t]{2}{*}{$\begin{array}{c}\text { Non- } \\
\text { pregnant* }\end{array}$} & \multicolumn{2}{|c|}{ Mid-pregnancy* } & \multicolumn{2}{|c|}{ Late pregnancy* } & \multicolumn{2}{|c|}{ Lactation $\dagger$} \\
\hline & & Single & Twin & Single & Twin & Single & Twin \\
\hline \multicolumn{8}{|l|}{$\begin{array}{l}\text { Glucose production } \\
\text { from }\end{array}$} \\
\hline Propionate & $13 \cdot 1$ & $11 \cdot 3$ & $13 \cdot 3$ & $18 \cdot 2$ & $17 \cdot 2$ & $30 \cdot 4$ & $36 \cdot 4$ \\
\hline $\mathrm{CO}_{2}$ & 7.8 & $8 \cdot 1$ & 7.4 & $6 \cdot 3$ & $5 \cdot 5$ & $11 \cdot 6$ & $14 \cdot 0$ \\
\hline Other metabolites $\ddagger$ & $22 \cdot 8$ & $27 \cdot 6$ & 27.6 & $28 \cdot 7$ & $39 \cdot 3$ & 50.5 & $53 \cdot 3$ \\
\hline Glucose utilization to $\mathrm{CO}_{2}$ & $28 \cdot 0$ & $35 \cdot 6$ & $28 \cdot 6$ & 28.4 & $36 \cdot 3$ & $45 \cdot 9$ & 32.2 \\
\hline
\end{tabular}

* Given $1200 \mathrm{~g}$ dried grass/d.

$\dagger$ Given $2500 \mathrm{~g}$ dried grass/d.

$\ddagger$ Derived by difference (i.e. glucose production rate-contribution from propionate and $\mathrm{CO}_{2}$ ).

\section{Models of glucose metabolism}

When the production rates and TQ values were fitted into the three-pool model (see Fig. 1) and analysed by matrix analysis, quantitative values for the transfer to glucose of $\mathrm{C}$ from propionate, $\mathrm{CO}_{2}$ and other metabolites, and the amounts of glucose oxidized to $\mathrm{CO}_{2}$ and diverted to other metabolites, were obtained (Table 3).

Non-pregnant and pregnant ewes given $1200 \mathrm{~g}$ dried grass $/ \mathrm{d}$. There was an increase of approximately $5 \mathrm{~g} \mathrm{C} / \mathrm{d}$ in the amount of propionate-C diverted to glucose in late pregnancy. This represented an increase in the percentage of the propionate resource which was diverted to glucose, from approximately $37 \%$ in the non-pregnant ewes and ewes in mid-pregnancy, to approximately $55 \%$ in late pregnancy. Because the GPR increased in late pregnancy the percentage of glucose-C supplied by propionate remained unchanged at approximately $29 \%$.

The contribution of $\mathrm{C}$ from metabolites other than propionate and $\mathrm{CO}_{2}$ (derived by difference) also appeared to increase in pregnancy (an additional $5 \mathrm{~g} \mathrm{C} / \mathrm{d}$ in mid-pregnancy and 6 and $16 \mathrm{~g} \mathrm{C} / \mathrm{d}$ in ewes carrying singles and twins in late pregnancy respectively) and provided from 52 to $63 \%$ of the GPR.

Approximately $62 \%$ of the glucose produced was oxidized directly to $\mathrm{CO}_{2}$.

Lactating ewes given $2500 \mathrm{~g}$ dried grass. In the lactating ewes approximately $34 \%$ of the glucose-C was derived from propionate. This represented $54-65 \%$ of the propionate-C produced.

Glucose oxidation could account for only 49 and $30 \%$ of the glucose produced in ewes suckling single and twin lambs respectively.

\section{DISCUSSION}

\section{The use of $\left[{ }^{3} \mathrm{H}\right] \mathrm{glucose}$ as a covariant}

The three-pool model approach adopted in these experiments was similar to that used by Egan et al. (1983) and MacRae \& Egan (1983) for determining the contribution which threonine- $\mathrm{C}$ made to glucose production in non-pregnant and pregnant ewes. This type of methodology has the advantage of providing not only estimates of the proportion of glucose derived from a specific precursor but also the proportions of glucose which are oxidized to $\mathrm{CO}_{2}$ and diverted to other metabolites. Ideally, estimates of the production rate of glucose and its precursor (in the present case, propionate) together with the proportion of the 
glucose-C derived from propionate should be determined simultaneously. Previous work has shown that this can be achieved in wether sheep by infusing the ${ }^{14} \mathrm{C}$-labelled precursor and $\left[{ }^{3} \mathrm{H}\right]$ glucose simultaneously, as $\left[{ }^{3} \mathrm{H}\right]$ glucose will give identical GPR values to those obtained using [ $\left.{ }^{14} \mathrm{C}\right]$ glucose (Judson \& Leng, 1972; Wilson et al. 1981). However, it is now known that $\left[{ }^{3} \mathrm{H}\right]$ glucose gives higher GPR values than does $\left[{ }^{14} \mathrm{C}\right] \mathrm{glucose}$ in pregnant and lactating ewes (Wilson et al. 1981) and indeed the comparison of the $\left[{ }^{3} \mathrm{H}\right]$ glucose and $\left[{ }^{14} \mathrm{C}\right]$ glucose in the present experiment showed that there was an $18 \%$ over-estimate of GPR using $\left[{ }^{3} \mathrm{H}\right]$ glucose in the pregnant and lactating ewes. For this reason it was necessary to infuse the $\left[{ }^{14} \mathrm{C}\right]$ glucose, $\left[{ }^{14} \mathrm{C}\right]$ propionate and $\mathrm{H}^{14} \mathrm{CO}_{3}$ on separate days and thereby build up the model over a period of approximately $10 \mathrm{~d}$. Consequently it was important to know whether the GPR stayed reasonably constant between these different infusions. For this reason $\left[{ }^{3} \mathrm{H}\right]$ glucose was used, in conjunction with each of the ${ }^{14} \mathrm{C}$-labelled tracers, as a covariant to monitor any changes in GPR which occurred between the different days of the infusion period.

Fortunately, in the majority of cases the GPR did not alter significantly over the period of the four different infusions (mean coefficient of variation $7 \%$ ) and so it was not necessary to make any major corrections for the modelling data.

\section{$G P R$}

In pregnancy. The demonstration of an increase in GPR in late pregnancy in ruminants has usually been associated with an increase in the level of feeding (Steel \& Leng, 1968, 1973; Lindsay, 1970; Bergman, 1973; Chaiyabutr et al. 1982). The present experiments, in agreement with those of MacRae \& Egan (1980, 1983), have demonstrated the ability of the pregnant ewe to increase glucose production significantly (by up to $50 \%$ in ewes carrying twin lambs in late pregnancy) in response to fetal demands, without any increase in the availability of propionate and whilst being in a state of moderate undernourishment (plasma 3-hydroxybutyrate concentrations of 1.6 (SE 0.22$) \mathrm{mM}$ ). This increase in GPR in late pregnancy (single fetus $9 \mathrm{~g} \mathrm{C} / \mathrm{d}$, twin fetuses $19 \mathrm{~g} \mathrm{C} / \mathrm{d}$ ) agreed very well with values quoted for umbilical uptake of glucose in late pregnancy (i.e. approximately $1.7 \mathrm{~g} \mathrm{C} / \mathrm{kg}$ fetus per $\mathrm{d}$; Paxson et al. 1978) and indeed, when values from the present experiments are considered along with those reported by MacRae \& Egan (1980), Hodgson et al. (1980) and Wilson et al. (1981) maternal GPR appears to be well correlated to total lamb birth weight (LBW): $(\mathrm{LBW}(\mathrm{kg})=-1 \cdot 7+0.25 \mathrm{GPR}(\mathrm{mmol} / \mathrm{h}), n 24, r 0.84)$. At the same time, the absence of any relationship between GPR and estimated metabolizable energy intake in late pregnancy in these same experiments suggests that the number and size of fetuses may be an important factor in determining GPR.

In lactation. It would appear that although there was some increase in GPR in response to the demands of suckling single or twin lambs (as evidenced by the slightly higher GPR associated with the ewes suckling twin lambs) dietary intake had a greater influence on GPR. Increasing the intake of non-pregnant ewes from 1200 to $2500 \mathrm{~g}$ dried grass/d in lactation was associated with a doubling of the GPR (see Table 1).

There is an absolute requirement for glucose in lactation, for the synthesis of lactose. It is also probable that there is a non-specific requirement for glucose for the synthesis of galactose, another precursor of lactose (Lindsay, 1979) and for the production of NADPH for fatty acid synthesis in the udder (Chaiyabutr et al. 1980). It would therefore be reasonable to assume that GPR could be one of the factors which influence milk production and consequently have some control over lamb growth rate. Some support for this hypothesis was provided by the results from the present experiments, where a significant relationship was obtained between GPR and the growth rate of suckling lambs (see Fig. 2). Two additional values have been added to Fig. 2 (not included in the regression) which 


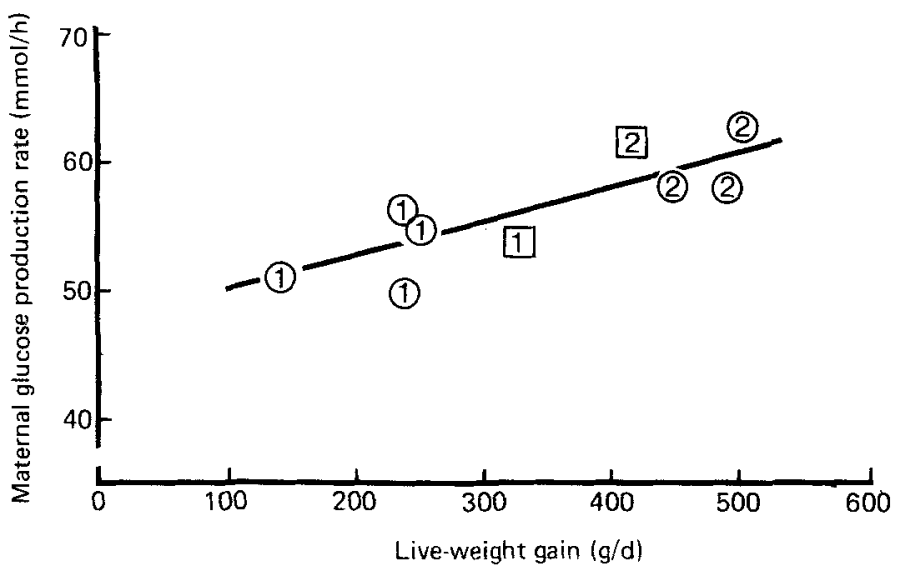

Fig. 2. The relationship between glucose production rate (GPR; $g$ carbon/d) in the ewe at approximately day 28 of lactation and live-weight gain ( $L W G ; g / d)$ of single (1) and twin (2), summation of $L W G$ of both lambs) lambs from birth to 5 weeks of age. GPR $(\mathrm{g} \mathrm{C} / \mathrm{d})=47.9+0.025 \mathrm{LWG}(\mathrm{g} / \mathrm{d}), r 0.8 .1$, 2 from previous experiment (Wilson et al. 1981) not included in the regression.

were derived from a previous experiment (Wilson et al. 1981) in which two ewes had a metabolizable energy intake similar to that fed in the present experiments. Further investigations into the relationships between glucose production, the production of milk constituents and the growth rate of suckling lambs may be justified.

\section{Glucose synthesis from propionate}

One of the interesting features of the values presented in Table 3 was the apparent increase in the proportion of the propionate- $C$ produced which was converted to glucose in late pregnancy and lactation. On this basis it could be argued that a metabolic adaptation had occurred in the ewes in response to the additional requirement for glucose. These values were calculated from TQ derived from the glucose SRA:propionate SRA value during infusion of [2-14 C]propionate. The use of this simple calculation has been questioned on the grounds that it may underestimate the contribution of propionate due to the 'crossover' of label in the TCA cycle (Black, 1970; Thompson, 1971; Young, 1977). Indeed, theoretical models have been proposed to calculate the extent of the problem (Thompson, 1971). They involve the determination of the proportion of oxaloacetate that goes to phosphoenolpyruvate (and then to glucose) by comparison of relative SRA values of either plasma glucose or blood $\mathrm{CO}_{2}$ obtained during infusion of $\left[1-{ }^{14} \mathrm{C}\right]$ propionate and $\left[2-{ }^{14} \mathrm{C}\right]$ propionate into the portal vein.

In the present experiment it was considered preferable to determine propionate production rates and the subsequent transfers of $\mathrm{C}$ to glucose following the infusion of propionate tracer directly into the rumen; TQ obtained using this method would then include any propionate-C that was transferred to glucose after first being converted to lactate during absorptive processes.

Similar infusion procedures were recently adopted in a study of the contribution of propionate-C to glucose in cattle given silage (Gill \& Beever, 1982), where Thompson's (1971) glucose ratio method was used to illustrate a possible underestimation of the contribution of propionate-C to glucose of approximately $40 \%$. The validity of using Thompson's (1971) glucose ratio correction in experiments where the two propionate tracers are infused into the rumen would seem to depend on the quantitative transfer of propionate 
across the rumen epithelium without any conversion of ${ }^{14} \mathrm{C}$-labelled propionate to lactate (which could subsequently be converted to glucose). Although the magnitude of such a conversion is arguable (Leng et al. 1967; Bergman \& Wolff, 1971; Weekes, 1972; Weekes $\&$ Webster, 1975) there seems little doubt that there is some conversion of propionate to lactate in the rumen epithelium, and this seriously questions the applicability of Thompson's (1971) glucose ratio correction method for rumen infusion studies.

The use of Thompson's other correction factor (i.e. the $\mathrm{CO}_{2}$ ratio method) would seem wholly inapplicable to the infusions of the two propionate tracers into the rumen since it has been demonstrated recently that during infusion of $\left[1-{ }^{14} \mathrm{C}\right]$ propionate into the rumen there is a large (up to $50 \%$ ) and rapid transfer of ${ }^{14} \mathrm{C}$ label to rumen $\mathrm{CO}_{2}$ (Mayes et al. 1981). For the present time, therefore, whilst being aware of the potential difficulties associated with the 'crossover' of label during intermediary metabolism, it is not possible to ascertain whether there is any need to modify the $\mathrm{C}$ transfer values in Table 3 . In fact Lindsay (1978) has presented evidence to suggest that the need to correct for 'crossover' in in vivo propionate-to-glucose experiments may not be as important as originally thought. This hypothesis was based on the observation that similar estimates of the proportion of glucose derived from propionate were obtained using the isotope dilution method (which should give a minimal estimate if 'crossover' is occurring) and the hepatic uptake method (which should give a maximum value if it is assumed that all the propionate taken up by the liver is used for glucose production).

\section{Glucose synthesis from other precursors}

In spite of the apparent increase in the contribution of propionate- $\mathrm{C}$ to glucose in pregnancy and lactation a large percentage of glucose- $\mathrm{C}$ was supplied by metabolites other than propionate and $\mathrm{CO}_{2}(55(\mathrm{SE} 1 \cdot 7) \%)$. When one starts to consider which other substrates could supply the substantial amounts of $\mathrm{C}$ required to balance the models one must first re-examine the meaning of GPR as determined by the isotope dilution method. By definition it is the rate at which glucose-C leaves the plasma pool and does not return during the infusion experiment. Any metabolites, therefore, such as lactate and glycogen, that are originally derived from glucose, appear to be turned over fairly rapidly and are probably used again for glucose synthesis during the time-course of the experiment, should not be considered as net precursors of glucose.

Glycerol is also synthesized from glucose and can be converted back into glucose. It is produced for fat synthesis and its release is therefore determined by the turnover rate of adipose tissue. Here, however, it would seem unlikely that significant amounts of the ${ }^{14} \mathrm{C}$ from glucose could be transferred to glycerol phosphate, then to triacylglycerols in adipose tissue and then be released in glycerol and converted back to glucose during the course of an infusion experiment. For this reason it is probably necessary to consider glycerol as a net precursor of glucose in the present experiments. Although no direct measurements were made of glycerol production rates, indirect estimates based upon plasma glycerol concentrations (non-pregnant $0.064 \mathrm{mM}$, pregnant $0.072 \mathrm{~mm}$, lactating $0.088 \mathrm{~mm}$ ) suggested that glycerol could have contributed a maximum of only 8-12 g C/d (Bergman, 1968). The remaining 40 (SE 1.9) \% of the GPR could not be accounted for and could have been derived from amino acids (see Table 4). The contribution of the essential amino acids such as threonine, methionine, isoleucine, valine and phenylalanine (Black, 1968; Black et al. 1970; Egan \& MacRae, 1979) appears to be of little significance in glucose synthesis in ruminants, but the contribution from the non-essential amino acids (NEAA) could be much greater. Indeed, glutamate, aspartate, alanine, serine and glycine have been shown to contribute up to $22,30,25,11$ and $7 \%$ of their flux-rates respectively to glucose synthesis (Egan et al. 1970; Wolff \& Bergmann, 1972; Heitmann et al. 1973; Bergman \& Heitmann, 1978). 
Table 4. The amounts of glucose-carbon $(\mathrm{g} / \mathrm{d})$ apparently derived from metabolites other than propionate, carbon dioxide and glycerol and the amount of glucose-C apparently diverted to metabolites other than $\mathrm{CO}_{2}$ in non-pregnant, pregnant and lactating ewes

\begin{tabular}{|c|c|c|c|c|c|c|c|}
\hline \multirow[t]{2}{*}{ Status of ewe... } & \multirow[t]{2}{*}{$\begin{array}{c}\text { Non- } \\
\text { pregnant }\end{array}$} & \multicolumn{2}{|c|}{ Mid-pregnancy } & \multicolumn{2}{|c|}{ Late pregnancy } & \multicolumn{2}{|c|}{ Lactation } \\
\hline & & Single & Twin & Single & Twin & Single & Twin \\
\hline $\begin{array}{l}\text { Glucose derived from } \\
\text { metabolites other than } \\
\text { propionate, } \mathrm{CO}_{2} \text { and } \\
\text { glycerol (i.e. probably } \\
\text { amino acids)* }\end{array}$ & $14 \cdot 8$ & $19 \cdot 6$ & $19 \cdot 6$ & $18 \cdot 7$ & $29 \cdot 3$ & $39 \cdot 5$ & $41 \cdot 3$ \\
\hline $\begin{array}{l}\text { Glucose diverted to } \\
\text { metabolites other than } \\
\mathrm{CO}_{2} \text { (i.e. possibly } \\
\text { amino acids) } \dagger\end{array}$ & $15 \cdot 7$ & $11 \cdot 4$ & $19 \cdot 7$ & $24 \cdot 8$ & $25 \cdot 7$ & $46 \cdot 6$ & $71 \cdot 5$ \\
\hline
\end{tabular}

* Glucose production rate-contribution from propionate $+\mathrm{CO}_{2}+$ glycerol.

$\dagger$ Glucose production rate-glucose oxidized.

\section{Glucose metabolism}

The observation that up to $40 \%$ of the glucose-C produced may come from the NEAA could initially be interpreted as imposing a severe drain upon the over-all $\mathrm{N}$ economy of the animal. However, when the amount of glucose that is oxidized directly to $\mathrm{CO}_{2}$ is taken into account (Table 3) it is possible to interpret the values in a slightly different way. In the non-pregnant and pregnant ewes only $62 \%$ of the GPR could be accounted for by oxidation to $\mathrm{CO}_{2}$, leaving $38 \%$ which could not be accounted for.

At present the fate of the glucose that is not oxidized remains uncertain. Under normal dietary conditions very little is thought to be used for fatty acid synthesis (Lindsay, 1970; Vernon, 1980) although a small amount will be used for glycerol phosphate synthesis for the production of triacylglycerols. In the present experiment the ewes were fed continuously and would probably have needed little short-term storage of glycogen. It therefore appears that the majority of the glucose that was not oxidized to $\mathrm{CO}_{2}$ in the non-pregnant and pregnant ewes may have been incorporated into NEAA. Some support for this hypothesis is provided by the appearance in tissue protein of appreciable amounts of ${ }^{14} \mathrm{C}$ after the injection of $\left[{ }^{14} \mathrm{C}\right]$ glucose into dairy cows (Black et al. 1955) and rats (Shipley et al. 1974; Haggarty et al. 1983). Indeed, in the present experiments there was a marked similarity between the amounts of glucose-C apparently derived from NEAA and the amount of glucose-C which was not oxidized to $\mathrm{CO}_{2}$, particularly in the non-pregnant and pregnant ewes (see Table 4). If it is assumed that the latter fraction consisted in the main of a diversion into NEAA, it could be interpreted as evidence to support the suggestion that the ruminant, like the non-ruminant, maintains its glucose and NEAA economies in an integrated interconversion system (MacRae \& Egan, 1980; Lindsay, 1982). If this is the case then the penalty on the $\mathrm{N}$ economy of the animal may only be small.

The percentages of glucose oxidized to $\mathrm{CO}_{2}$ in the lactating ewes (single $49 \%$, twin $30 \%$ ) were much lower than in the non-pregnant and pregnant ewes. This agreed with previous estimates (Bickerstaffe et al. 1974; MacRae \& Egan, 1980) and probably indicates a considerable 'exporting' of glucose for the synthesis of lactose and possibly galactose (another precursor of lactose) for milk production. This would account for the disparity 
between the amount of glucose-C apparently derived from NEAA and the amount of glucose- $\mathrm{C}$ diverted to metabolites other than $\mathrm{CO}_{2}$ in the ewes suckling twin lambs (see Table 4).

\section{REFERENCES}

Bergman, E. N. (1968). American Journal of Physiology 215, 865-873.

Bergman, E. N. (1973). Cornell Veterinarian 63, 341-382.

Bergman, E. N. \& Heitmann, R. N. (1978). Federation Proceedings 37, 1228-1232.

Bergman, E. N., Roe, W. E. \& Kon, K. (1966). American Journal of Physiology 211, 793-799.

Bergman, E. N. \& Wolff, J. E. (1971). American Journal of Physiology 221, 586-592.

Bickerstaffe, R., Annison, E. F. \& Linzell, J. L. (1974). Journal of Agricultural Science, Cambridge 82, 71-85.

Black, A. L. (1968). In Isotope Studies on the Nitrogen Chain, pp. 287-309. Proceedings of Symposium, IAEA, Vienna.

Black, A. L. (1970). In Physiology of Digestion and Metabolism in the Ruminant, pp. $452-455$ [A. T. Phillipson, editor]. Newcastle upon Tyne: Oriel Press.

Black, A. L., Kleiber, M. \& Baxter, C. F. (1955). Biochimica et Biophysica Acta 17, 346-353.

Black, A. L., Thompson, J. R., Anand, R. S. \& Chapman, T. E. (1970). In Energy Metabolism of Farm Animals, pp. 73-76 [A. Schurch and C. Wenk, editors]. Zurich: Juris Verlag.

Brockman, R. P. \& Greer, C. (1980). Australian Journal of Biological Science 33, 457-464.

Chaiyabutr, N., Faulkner, A. \& Peaker, M. (1980). Biochemical Journal 186, 301-308.

Chaiyabutr, N., Faulkner, A. \& Peaker, M. (1982). British Journal of Nutrition 47, 87-94.

Corbett, J. L., Farrell, D. J., Leng, R. A., McClymont, G. L. \& Young, B. A. (1971). British Journal of Nutrition 26, 277-291.

Egan, A. R. \& MacRae, J. C. (1979). Annales de Recherches Vétérinaires 10, 376-378.

Egan, A. R., MacRae, J. C. \& Lamb, C. S. (1983). British Journal of Nutrition 49, 373-383.

Egan, A. R., Moller, F. \& Black, A. L. (1970). Journal of Nutrition 100, 419-428.

Gill, M. \& Beever, D. E. (1982). British Journal of Nutrition 48, 37-47.

Gutteridge, J. M. C. \& Wright, E. B. (1968). Journal of Medical and Laboratory Technology 25, 385-386.

Haggarty, P., Reeds, P. J. \& Wahle, K. W. J. (1983). In Energy Metabolism of Farm Animals, pp. 156-159 [A. Ekern and F. Sundstøl, editors]. Ski, Norway: Informasjonsteknikk A/S.

Heitmann, R. N., Hoover, W. H. \& Sniffen, C. J. (1973). Journal of Nutrition 103, 1587-1593.

Hill Farming Research Organisation (1979). Science and Hill Farming: HFRO Silver Jubilee Report 1954-1979, p. 41. Haddington, Scotland: D. \& J. Croal.

Hodgson, J. C., Mellor, D. J. \& Field, A. C. (1980). Biochemical Journal 186, 739-747.

Jones, G. B. (1965). Analytical Biochemistry 12, 249-258.

Judson, G. J. \& Leng, R. A. (1968). Proceedings of the Australian Society of Animal Production 7, $354-358$.

Judson, G. J. \& Leng, R. A. (1972). Australian Journal of Biological Science 25, 1313-1332.

Leng, R. A. (1970). Advances in Veterinary Science and Comparative Medicine 14, 209-260.

Leng, R. A. \& Leonard, G. J. (1965). British Journal of Nutrition 19, 469-484.

Leng, R. A., Steel, J. W. \& Luick, J. R. (1967). Biochemical Journal 103, 785-790.

Lindsay, D. B. (1970). In Physiology of Digestion and Metabolism in the Ruminant, pp. 438-451 [A. T. Phillipson, editor]. Newcastle upon Tyne: Oriel Press.

Lindsay, D. B. (1978). Biochemical Society Transactions 6, 1152-1156.

Lindsay, D. B. (1979). Proceedings of the Nutrition Society 38, 295-302.

Lindsay, D. B. (1982). Federation Proceedings 41, 2550-2554.

MacRae, J. C. \& Egan, A. R. (1980). In Energy Metabolism, pp. 421-426 [L. E. Mount, editor]. London and Boston: Butterworths.

MacRae, J. C. \& Egan, A. R. (1983). British Journal of Nutrition 49, 385-393.

MacRae, J. C. \& Wilson, S. (1978). International Journal of Applied Radiation and Isotopes 29, 191-195.

Mayes, R. W., Milne, J. A., Lamb, C. S. \& Spence, A. M. (1981). Proceedings of the Nutrition Society 40, 9 A.

Nolan, J. V., Norton, B. W. \& Leng, R. A. (1976). British Journal of Nutrition 35, 127-147.

Paxson, C. L. Jr, Morris, F. H. Jr. \& Adcock III, E. W. (1978). Pediatric Research 12, 864-867.

Prieto, C., MacRae, J. C., Brockway, J. M. \& Lobley, G. E. (1983). In Energy Metabolism of Farm Animals, pp. 70-73 [A. Ekern and F. Sundstøl, editors]. Ski, Norway: Informasjonsteknikk A/S.

Shipley, R. A., Gibbons, A. P. \& Chudzik, E. B. (1974). Canadian Journal of Physiology and Pharmacology 52, 797-807.

Steel, J. W. \& Leng, R. A. (1968). Proceedings of the Australian Society of Animal Production 7, 342-347.

Steel, J. W. \& Leng, R. A. (1973), British Journal of Nutrition 30, 451-473.

Thompson, J. R. (1971). Gluconeogenesis from propionate in the lactating cow. PhD Thesis, University of California, Davis, USA.

Vernon, R. G. (1980). Progress in Lipid Research 19, 23-106.

Weekes, T. E. C. (1972). Journal of Agricultural Science, Cambridge 79, 409-421.

Weekes, T. E. C. \& Webster, A. J. F. (1975). British Journal of Nutrition 33, 425-438. 
Wilson, S. (1982). Glucose metabolism in hill sheep. PhD Thesis, University of Nottingham.

Wilson, S., MacRae, J. C. (1977). Journal of Agricultural Science, Cambridge 88, 245-246.

Wilson, S., MacRae, J. C. \& Buttery, P. J. (1979). Research in Veterinary Science 26, 256-258.

Wilson, S., MacRae, J. C. \& Buttery, P. J. (1981). Research in Veterinary Science 30, $205-212$.

Wilson, S., MacRae, J. C. \& Buttery, P. J. (1983). In Energy Metabolism of Farm Animals, pp. $38-41$ [A. Ekern and F. Sundstøl, editors]. Ski, Norway: Informasjonsteknikk A/S.

Wolff, J. E. \& Bergman, E. N. (1972). American Journal of Physiology 223, 455-460.

Young, J. W. (1977). Journal of Dairy Science 60, 1-15.

Ziolecki, A. \& Kwiatkowska, E. (1973). Journal of Chromatography 80, 250-254. 